\title{
Integrating complementary/alternative medicine into primary care: evaluating the evidence and appropriate implementation [Corrigendum]
}

\author{
Wainapel SF, Rand S, Fishman LM, Halstead-Kenny J. Int $J$ \\ Gen Med. 2015;8:361-372.
}

On page 364, left column, line 15, Doctor of Osteopathy should have been Doctor of Osteopathic Medicine.

International Journal of General Medicine

\section{Publish your work in this journal}

The International Journal of General Medicine is an international, peer-reviewed open-access journal that focuses on general and internal medicine, pathogenesis, epidemiology, diagnosis, monitoring and treatment protocols. The journal is characterized by the rapid reporting of reviews, original research and clinical studies across all disease areas.

A key focus is the elucidation of disease processes and management protocols resulting in improved outcomes for the patient. The manuscript management system is completely online and includes a very quick and fair peer-review system. Visit http://www.dovepress.com/ testimonials.php to read real quotes from published authors. 